\title{
Merleau-Ponty, Correlationism, and Alterity
}

\author{
ROBERT BOOTH
}

Speculative realists claim that phenomenologists cannot address other entities in the more-than-human world on their own terms because phenomenology is paradigmatically correlationist. The standard charge of correlationism holds that because the phenomenological subject actively structures its entire experience, phenomenology effectively reduces the world to a correlate for the subject, rather than addressing the world as it exists beyond, or before the (human) subject. Since, under correlationism, worldly entities are purportedly revealed in a manner non-accidentally related to their place in an anthropocentric schema, correlationism allegedly leads to unpalatable conclusions (e.g. technoscientific instrumentalism, large-scale environmental degradation caused by rampant consumerism, exclusionary anthropocentric politics) for the more-than-human world (see e.g. Morton "Everything"). In this paper, I will address the charge of correlationism against Merleau-Pontian phenomenology in two steps. Firstly, I intend to show that although Merleau-Pontian phenomenologists must court something like correlationism, this is because of a well-justified desire to retain the alterity of other parties revealed in experience, serious engagement with which requires addressing the situated body-subject's irreducible contribution to the character of any world taken up. Secondly, I intend to problematize the claim that this sort of admission necessarily makes Merleau-Pontian phenomenology correlationist, at least in any problematic sense. On my account, any serious version of the correlationist charge is misdirected because Merleau-Pontians deny the ontological primacy of the poles between which correlational "access" is said to occur. Ultimately, I hope to show that by reinstating the centrality of the body to phenomenological investigation, and thus facilitating a chiasmic epistemic relationship between body-subject and world, a radically-reflective phenomenology of a Merleau-Pontian ilk can nullify the problems supposedly introduced by correlationism even if, at some level of description, the charge may be true. 


\section{Correlationism}

Speculative realism is widely recognized to be a diverse movement united only by its formal rejection of correlationism and the desire to overcome it in one way or another (Sparrow 115; Shaviro 65). So, what exactly is correlationism?

In a statement more-or-less echoed by all speculative realists, Quentin Meillassoux holds that "by 'correlation' we mean the idea according to which we only ever have access to the correlation between thinking and being, and never to either term considered apart from the other." Since the correlation is "unsurpassable. ... Correlationism consists in disqualifying the claim that it is possible to consider the realms of subjectivity and objectivity independently of one another" (5). Phenomenologists like Merleau-Ponty resist cleaving epistemology from ontology because one's phenomenological opening is the only means of establishing any such ontology. However, as Merleau-Ponty argues, any phenomenology worth its salt also recognizes that the phenomenological subject actively structures the "concrete physiognomy" of its experience (Phenomenology 57). Phenomenology seems, therefore, only to be able to make sense of the world as an intentional correlate for a subject, rather than the world as it is in-itself. As a phenomenologist, it is claimed, one therefore has no means of access to any stipulative world outside of the correlative schema.

There are several strands to the criticism that, in this manner, correlationism (and therefore phenomenology) leads to the sort of dangerous consequences mentioned at the outset, three of which I will examine in turn.

\section{(a) The Subjectivism Problem}

Since the bounds of the correlation are unbreachable, it seems that "[n]othing that is in the correlation can be used to adjudicate differing claims about what is outside the correlation" (Richmond 400). Thus, for Meillassoux at least, by rejecting the absolutism of the thing-in-itself, "correlational reason thereby legitimates all those discourses that claim access to an absolute, the only proviso being that nothing in these discourses resembles a rational justification of their validity" (Meillassoux 44-5). Since correlationism apparently reduces the scope of philosophical argumentation about other entities to fideistic belief, correlationism seems to result in a sort of radical subjectivism, implicitly stacked in favour of the (human) subject, regarding how one should perceive, understand, and treat (nonhuman) objects. To clarify: this is not because any belief about a given entity can be put to a subjective court of appeal which somehow reasons to its ultimate justification, but rather because the fideism that allegedly results from correlationism "legitimates de jure every variety whatsoever of belief in an absolute, the best as well as the worst" (Meillassoux 46). Thus, 
although the correlationist affirms the fundamental (anthropocentric) asymmetry of the epistemic relationship between subject and object, under correlationism, any belief that a (human) subject might have about a (nonhuman) object is rendered just as legitimate as any other simply in virtue of its being believed.

\section{(b) The Intersubjectivity Problem}

Of course, the above is only part of the story. Correlationists have means within the correlation with which to adjudicate truth claims, but only through the sort of intersubjective consensus employed by Kant and Husserl. One putative problem with such appeals is that since the intersubjective community is, in effect, exclusively human, consensus entrenches a "species solipsism" (Meillassoux 50) whereby species norms usurp the primacy of an (unknowable) reality beyond that community. ${ }^{1}$ Similar, if not worse, effects are therefore licensed, since species solipsism mistakes the human perspective for reality. Thus, we might plausibly expect anthropocentric instrumentalization to follow from correlationism in a similar manner to the one that concerned Heidegger about technology (i.e. by implicitly characterizing nonhuman entities in terms of their use-valuefor-us, albeit through a disinterested façade).

\section{(c) The Problem of Human Exceptionalism}

Timothy Morton calls correlationism "anthropocentrism in philosophical form" ("Everything" 164) for some of the above reasons, but he also contends that the correlationist focus on acts of meaning constitution turns us away from concern for the world itself by imposing a mistaken human exceptionalism. This problem has two dimensions. In the first place, if objects exist only for subjects, and subjects are effectively ubiquitously human, then philosophy is purportedly drawn away from concern for "the real world" and instead towards description of "my world." This would prove disastrous in terms of a reduced push to address other entities on their own terms. These terms, speculative realists claim, cannot be "[p]recisely the terms concomitant with the first-person phenomenological point of

\footnotetext{
${ }^{1}$ Husserl holds that the world's "objectivity" may also be intersubjectively co-constituted by trans-species Others (Cartesian Meditations 106-7). Nevertheless, Meillassoux would think that, under correlationism, any nonhuman "intersubjective" contributions could only be grasped by subsuming them under the narrowly anthropocentric terms of the correlationist circle. This is because, Meillassoux claims, transcendental subjectivity is confined to a "transparent cage": the specific, incarnated, "point of view" in which a subject is "instantiated" and which exhaustively dictates the terms of any critical enquiry (7; 245). Although we should have misgivings about Meillassoux's argument, we should note that Husserl does sometimes homogenize the "intentional and epistemic essence[s]" of acts by which objects are perceived in a manner not obviously sufficiently hospitable to the alterity of nonhuman subjects (see, for instance, Logical Investigations II 314-6).
} 
view" (Brassier 27). This allegedly anthropocentric shift also seems to speak against taking up the toil of environmental engagement since, as Simon James puts it, "[t]o think that mountain streams, humpback whales, and Californian redwoods need our care and attention, one must presumably see these things ... as enjoying some kind of existence in their own right" ("Merleau-Ponty" 502). ${ }^{2}$

The second aspect of anthropocentric exceptionalism concerns turning away from the real things themselves, a move that belies the mistaken ontological bifurcation of human subjects and (entities in) nature. Here, the sort of subject/object cleavage imposed by correlationism allegedly contains, or at least facilitates, a dualistic hierarchy of kind, value, and the like. For Morton, this is largely because correlationism cleaves human subjects - who retain a constitutive monopoly on epistemological and ontological matters - from natural objects, which are plastic insofar as they lack any significant resistance to their ontological and epistemological subsumption under the interested correlational terms of human subjects. Thus, correlationism cannot obviously decentre the human perspective in the manner necessary for serious environmental concern. ${ }^{3}$

In these ways philosophy, since the second Copernican turn-or "Kantian catastrophe" (Meillassoux 124) — appears to have been hopelessly and dangerously introverted because, even in acts of radical reflection, it cannot escape the "correlationist circle" (Meillassoux 5). In such a circle, entities cannot be addressed on their own terms without the caveat "for us." For phenomenologists, this "for us" is explicitly tied to one's (human) intentional horizon. Thus, the anticorrelationist argument goes, because of its paradigmatic commitment to correlationism, phenomenology is

\footnotetext{
${ }^{2}$ James associates this sort of argument for metaphysical realism with Holmes Rolston III. Rolston makes a similar (though less technical) ancestrality argument to Meillassoux's by referring to the "lion objects" that must temporally precede one's identification of them as such (52-5). Meillassoux's ancestrality argument holds that phenomenology relies on a world that precedes human consciousness because consciousness requires such a world to emerge. Phenomenology, however, appears unable to even think about the sort of world it requires. Engaging fully with the ancestrality argument goes beyond the scope of this paper. I will, however, gesture in the direction of a response via Merleau-Ponty's identification of lateral kinship in section five.

${ }^{3}$ Morton claims that resistance to "Western ideas of the subject as transcendence" requires re-construing "everything as objects" ("Everything" 168), as well as recognizing that "[t]here is no Nature, only people, some of whom are human beings" ("Ecologocentrism" 77). Although Morton's solution to this problem differs radically from Meillassoux's, the basic objection is consistent with Meillassoux's lament that, through specifically correlational subject/object relations, "contemporary philosophers have lost the great outdoors, the absolute outside of precritical thinkers: that outside which was not relative to us, and which was given as indifferent to its own givenness to be what it is, existing in itself regardless of whether we are thinking it or not; that outside which thought could explore with the legitimate feeling of being on foreign territory - of being entirely elsewhere" (Meillassoux 7).
} 
problematically incompatible with nonanthropocentric epistemic engagement with the more-than-human world. ${ }^{4}$

\section{Why Regard for Alterity Requires Something Like Correlationism}

In order to respond to these charges, I will first discuss how the requirement not to overwrite nonhuman alterity, which underwrites all three objections, may actually speak in favour of adopting something like a correlationist philosophy.

One plausible place to begin is Merleau-Ponty's analysis of the Other. As a matter of inescapable "perceptual faith" (Merleau-Ponty, Visible 18), I recognize that the Other opens onto a common world, which may nevertheless differ by significant degree from my own (Visible 141). There can, however, be no possibility of their perspective presenting itself to me without collapsing that alterity. If the Other were "given to me such as he is present to himself ... the fusion of its ego with mine would cause its alterity to disappear" (Barbaras 128). Others, it seems, are given to us fundamentally ambiguously: neither as pure positivity (object), nor-given the commonality of our world — as pure lack (subject).

It seems plausible to suggest that if we cannot subsume the Other into ourselves via reducing them to an object, then we should be attentive to the limits of our own worlds and any "objects" therein. Addressing the Other in her alterity in a manner that evades an erroneous ontological and epistemological imperialism seems to require that one first recognizes that "how the world is for me" cannot be unproblematically universalized. One crucial limitation on doing so is that one's concrete body is a necessary condition for having one's world, because one's body "opens [one] out upon the world and places [one] in a situation there" (Merleau-Ponty, Phenomenology 165).

Merleau-Ponty argues that epistemological and ontological claims always rely on the primacy of the phenomenal perspectives in the context of which they (via the natural sciences and so on) derive their usefulness and truth-value (Phenomenology viii). Merleau-Ponty then argues that one's embodiment contributes the most important co-determinant of the way the world is presented, since our expectations of truth or reality are tied to our bodily capacities as the medium of having a world in the first place (146). "A thing", Merleau-Ponty argues, is "not actually given in

\footnotetext{
${ }^{4}$ Merleau-Pontian phenomenology adheres to an expressive theory of truth, under which an entirely independent thing-in-itself cannot be grasped. This commitment purportedly puts Merleau-Ponty in a worse position (strong correlationism) than Kant (weak correlationism). Kant at least thinks that the thing-in-itself can be thought, and must exist, even if it cannot be known without anthropocentric filtering via the categories (see Meillassoux 35).
} 
perception, it is internally taken up by us, reconstituted and experienced by us insofar as it is bound up with a world, the basic structures of which we carry with us" (326). One's primordial relationship with(in) the world is, therefore, operatively intentional: one's embodied expectations codetermine the meanings that the world expresses via the essential "grip" in which "my motor intentions, as they unfold, receive the responses they expect from the world. This maximum distinctness in perception and action points clearly to a perceptual ground, a basis of my life, a general setting in which my body can co-exist with the world" (250).

Certain of these expectations will be related to human scale, for instance, visual and olfactory limitations, and the like. Merleau-Ponty also argues, however, that perception is always subject to habitual sediment via the "intentional arc" that "projects round us our past, our future, our human setting, our physical, ideological and moral situation, or rather which results in our being situated in all these respects" (136). Here, knowledge is sedimented into habits that normatively "enrich and recast the body schema" (153) at the pre-reflective level. Furthermore, as Sara Heinämaa argues, for Merleau-Ponty, perception is also the product of the sediment of our "intentional ancestors" in the sense that one always takes up "an entire tradition of sensing and perceiving" (282), whereby "my body and my senses are precisely that familiarity with the world born of habit, that implicit or sedimentary body of knowledge" (Merleau-Ponty, Phenomenology 238).

What all of this means is that reality is expressed from within a situation, which one cannot plausibly transcend. Even if one were able to overcome historico-cultural sediment in order to return to a pre-sedimentary situation, that would still be from within the remit of a concrete human body, the grounding perceptual norms of which will not straightforwardly map onto all biotic entities, let alone allow one to exhaustively express the perceiver-independent reality of any putative abiota-in-itself.

It is not my intention to defend this view in detail here. The salient point is that recognition of one's contribution to the pre-thematic reality that underwrites ontological and epistemological claims is given central prominence in Merleau-Pontian phenomenology. As a result, for MerleauPonty, philosophy is properly characterised as radical reflection: the perpetual process of attempting to slacken one's "intentional threads" (Phenomenology xii) to better appreciate the basic intentional structures that one co-constructs with the world. But Merleau-Ponty is also expressly concerned with the chiasmic encroachments that radical reflection might reveal with other epistemic body-subjects and, consequently, the overlaps and inexhaustible differences in the meaningful ways the world might be 
expressed. ${ }^{5}$ If one's differential embodiment is as epistemologically pivotal as Merleau-Ponty claims, then it stands to reason that one task for radical reflection must be to maintain an interrogative focus on uncovering where one might (implicitly) overwrite the alterity of other entities via the imposition of situated (and sedimented) ways of perceiving as universal truth. In doing so, Merleau-Pontian phenomenology may take entirely seriously the thought that expressive truth rules out the plausibility of exhaustive accounts of (particular elements of) reality by taking to heart Levinas's thought that objectification involves subsuming all truths into mine: it is "the reduction of the other to the same" (Levinas, "Infinity" 48). Merleau-Pontian phenomenology is, after all, principally defined by its hostility to the sort of ontological and epistemological objectification criticized by Levinas. ${ }^{6}$ This enables Merleau-Pontian phenomenologists to set out their nonanthropocentric stall.

Now, given that "man [sic] is in the world, and only in the world does he know himself" (Merleau-Ponty, Phenomenology x-xi), there can be no coincidental reflective return to the things themselves in Brassier's sense. This seems to make Merleau-Pontian phenomenology correlationist.

\footnotetext{
${ }^{5}$ An optic chiasm is a part of the brain in which one's optic nerves partially cross. Although the nerves are not themselves photosensitive, their crossing-over is essential for binocular vision. Merleau-Ponty's ontological and epistemological chiasms work in much the same way: whilst chiasmic poles (e.g. subject-object; self-Other; sentient-sensible) are not identical, neither are they entirely distinct, because the ontological fissure that separates them is also a (carnal) bond which allows the reciprocal exchange between poles constitutive of perceptual expression. For Merleau-Ponty, just as monocular vision is abstracted from binocular vision, "subject" and "object" are reflective abstractions from their ordinary co-constitutive expressive contexts. For Merleau-Ponty, partial encroachment between chiasmic poles, and not their juxtaposition or assimilation, is ontologically basic (see Phenomenology 93; Visible 7-9; 123; 148; 225).
}

6 To clarify: Levinas (e.g. "Outside" 96-103) holds that, by understanding Others in epistemological terms, Merleau-Ponty misses the ethical moment of radical alterity. For Levinas, ethical engagement with alterity requires a "nonreciprocal relationship" (Time 83) between parties. Levinas's critique, however, misses the mark on two counts: Firstly, Levinas fails to appreciate that for Merleau-Ponty, as ambiguously embodied bodysubjects who share chiasmic openings onto the world, identity and alterity become largely matters of degree rather than kind. It is straightforwardly false, therefore, to think that a partial epistemic reciprocity entails, or even necessarily seeks, an ethically suspect relationship of objectivistic assimilation in the manner Levinas thinks. Secondly, as Jack Reynolds (315-7) has argued, Levinas also fails to appreciate that one can elicit from Merleau-Ponty's works a certain ethical salience to the possibility of dialogical reciprocity between parties that can only really be facilitated by a degree of epistemic encroachment. As Sally Fischer (210-1) puts it, for Merleau-Ponty, "[i]t is not just a matter of simply recognising that there is another, with a view different from my own. Rather, ethical recognition is a mode of being with another; it demands that the other be listened to as another possible perspective while still attempting to maintain the goal of genuine reciprocity.... [T] here is an obligation, a pact to keep the communicative process alive." 
What I want to argue here is that if something like correlationism is the price to pay for an intrinsic focus on perpetually addressing one's own imposition of ontological and epistemological violence, then we Merleau-Pontians should cheerfully accept the charge (or something like it).

Of course, this may all be too quick. Speculative realists argue that they are suitably reflexive about such violence, while also maintaining the realism that is seemingly essential to avoiding disastrous environmental implications. After all, no speculative realist claims to have unfettered access to reality-in-itself. Rather, they claim that reality can be (speculatively) known in part. It seems, however, that the brand of realism they employ ultimately speaks against their capacity to maintain sufficient reflexivity.

\section{Correlationism and the Realism/Idealism Binary}

One underlying problem derives from speculative realists mistaking phenomenological "correlationism" for an (anthropocentric) absolutizing of the subject pole, which is something to be avoided at all costs. In much of the speculative realist literature (e.g. Meillassoux 18; Sparrow 26), a binary is set up between idealism and realism whereby correlationism-where one denies epistemic access to the in-itself-is considered enough to commit one to a full-blown metaphysical idealism. Although I have no space to discuss it here, this claim is misleading, even when directed at the alleged arch-correlationist: Kant. To his credit, however, Harman attempts to address this conflation of epistemology with metaphysics head on, so I will explore his argument more fully.

Harman argues that correlationism commits one to a de facto metaphysical idealism because correlationism precludes access to the world-in-itself and thus entails that the world is treated in an idealistic manner by the correlationist. That is, under correlationism, one absolutizes the subject pole as a matter of praxis, and this explains why correlationism leads to the sort of disastrous consequences outlined at the outset. If one has no epistemic access to the glacier in-itself, the argument goes, the glacier is effectively reduced to the way it appears to perspectives like mine. Harman, therefore, proposes a "litmus test" for idealism: "Of any philosophy we encounter, it can be asked whether it has anything to tell us about the impact of inanimate objects upon one another, apart from any human awareness of this fact" (Guerrilla 42). Answering "no" to this question, Harman thinks, "condemn[s] philosophy to operate only as a reflexive meta-critique of the conditions of knowledge" (42).

We might have reservations about much of this argument, but for the sake of brevity, I will focus on one response available to the phenomenologist. It might be claimed that Merleau-Pontian 
phenomenology can pass Harman's own test and, therefore, escape the de facto idealism levelled against it. It may do so because Merleau-Ponty thinks that we only perceive whole "objects" since perspectives licenced by other entities themselves form constitutive parts of one's own perception.

To explain: Sean Kelly has compellingly argued that for MerleauPonty, one is always implicitly acquainted with positions of optimality that, as part of the normative background of perception, direct "my gaze and [cause] me to see the object" (Merleau-Ponty, Phenomenology 310) as I do. In the case of colour perception, for example, one is only ever "objectively" party to perspectival instantiations of lighting and particular shades. Nevertheless, what one perceives is the constant, real colour, albeit differently situated. As Kelly puts it, "I see how the lighting should change in order for me to see the colour better" (83). For Merleau-Ponty, these optimal norms appear to be understood at the pre-reflective, bodily level because "[ $\mathrm{t}]$ he real colour persists beneath appearances as the background persists beneath the figure, not as a seen or thought-of quality, but through a non-sensory presence" (Phenomenology 305).

The optimal point of observation for three-dimensional objects like houses, glaciers, and Californian redwoods, however, is one that reveals features from all sides and so cannot be even ideally instantiated. Nevertheless, it remains "the norm ... with respect to which all actual points of view are understood" (Kelly 92). This is why Merleau-Ponty (in)famously claims that "the house itself is not the house seen from nowhere, but the house seen from everywhere" (Phenomenology 69). As Kelly points out, Merleau-Ponty cannot thereby mean to refer to how the hidden sides would appear if $I$ were to go and look at them, because those other perspectives are manifest parts of my current perception (100). This claim is exemplified in the following passage:

To see is to enter a universe of beings which display themselves ... to look at an object is to inhabit it, and from behind this habitation to grasp all things in terms of the aspect which they present to it. But insofar as I see those things too, they remain abodes open to my gaze and, being potentially lodged in them, I already perceive from various angles the central object of my present vision. (MerleauPonty, Phenomenology 68)

The present perspectives of other entities (in which one is lodged, and which are licenced by the object itself) constitute part of the normative background to one's perception because "every object [really] is the mirror of all others" (68). ${ }^{7}$ Thus, one might plausibly claim, Merleau-Pontian phenomenology does have something to tell us about inter-objective

\footnotetext{
${ }^{7}$ Making this claim plausible requires an appeal to the ontological continuity that carnality provides. I explore this continuity in section five.
} 
relations without reducing them to one's own awareness of those relations in the manner necessary to implicate one in idealism.

To clarify: accepting the partiality of situated perspective is the starting point of object-oriented ontology. Harman therefore cannot think that the mere fact that one's knowledge of inter-objective encounters is always gleaned from a perspectival position of awareness is enough to render a philosophy idealist without undermining the realism of his own project. Neither can he maintain that idealism is entailed by the mere fallibility of knowledge claims made about inter-objective relationships. Like Meillassoux, Harman readily accepts the fallibility of speculative knowledge claims. In terms of other entities, there needs to be a stronger epistemic reduction to, or metaphysical dependence on, human awareness to entail de facto idealism. But Merleau-Ponty does not invoke either of these relationships.

Nevertheless, Harman cites the very passage in question as an example of Merleau-Ponty's idealism, calling it "a metaphysics of relations" (Guerrilla 50). Harman argues that if an entity is reduced to a view-from-everywhere that leaves "nothing hidden," as Merleau-Ponty claims (Phenomenology 79), then the latter is effectively advancing an idealist metaphysics (Guerrilla 51). This is because, Harman argues, the entities in question are ultimately nothing more than the multiple human perspectives in which they feature. After all, Merleau-Ponty does not engage in the sort of panpsychist or animist anthropomorphism under which glaciers, rocks, and neutrinos really perceive one another in the absence of body-subjects. $^{8}$ A metaphysics of relations, for Harman, is tantamount to idealism and is purportedly exemplified by Merleau-Ponty's consistent reduction of the in-itself to an "in-itself-for-us" (Merleau-Ponty, Phenomenology 322). Harman goes as far as to claim that Merleau-Pontian phenomenology adheres to a pseudo-Kantian metaphysics under which reality is "a vast homogenous totality until humans burst onto the scene" (Guerrilla 52). If Harman's critique holds, then Merleau-Pontian phenomenology does seem to absolutize the human subject in an anthropocentric manner.

However, Harman misunderstands what Merleau-Ponty means by "in-itself-for-us." For Merleau-Ponty, the "inexhaustible" (Phenomenology

${ }^{8}$ Even in Merleau-Ponty's later ontology, the sensible-sentient chiasm is only a "remarkable variant" (Visible 136) of fleshy relations. There is no requirement for universal sentience. In fact, Merleau-Ponty explicitly rejects it (Visible 39; 136; 250).

${ }^{9}$ We should heed Merleau-Ponty's warning about linguistic distortion in the terminology he employs. For Merleau-Ponty, an entity "is not first of all a meaning for the understanding, but a structure accessible to inspection by the body, and if we try to describe the real as it appears to us in perceptual experience, we find it overlaid with anthropological predicates" (Phenomenology 320). 
xvii) contribution of the world with(in) which I communicate is an essential co-determinant of reality that is irreducible to Harman's idealistic characterization. Although the world shows up only in particular expressions as integrated, diacritically-interrelated wholes, Merleau-Ponty is adamant that the world retains what James calls a "brute presence" that is irreducible to acts of perception, which is the very reason why our intersubjective world is unavoidably common in the first place (James, "Merleau-Ponty" 507; Merleau-Ponty, Phenomenology 320-4). Thus, although the view-from-everywhere provides normative ontoepistemological guidance, entities are not thereby reduced to the sum of all "subjective" perspectives because they co-express themselves in or through those perspectives. One might not be able to make sense of a pre-expressive, autonomous reality, but reality does not thereby become mine in any accurate sense. There is, after all, a meaningful distinction to be made where "I cannot say that $I$ see the blue of the sky in the same sense in which I say that I understand a book or again in which I decide to devote my life to mathematics" (Merleau-Ponty, Phenomenology 215). One cannot communicate alone.

However, Harman or Meillassoux might respond that this still doesn't satisfy the more fundamental objection that phenomenology remains idealistic insofar as it is incompatible with epistemic access to objects, properties, or relations in-themselves. After all, Meillassoux would contend, since Merleau-Ponty concedes that the view-from-everywhere can be only a "presumptive synthesis" (Phenomenology 90) on the part of the body-subject(s), rather than being straightforwardly ontologically manifest, Merleau-Pontian phenomenologists remain unable to say anything about the perceiver-independent absolute. Other promising examples cited by Kelly, such as the one where "the lighting directs my gaze and causes me to see the object, so that in a sense it knows and sees the object" (Merleau-Ponty, Phenomenology 310), fare little better on this score because, for all its extrahuman normative impetus, if the "view from nowhere ... is a contradiction" (Phenomenology 67), then "the object" can never be understood entirely independently of the gaze in which it manifests itself.

Whilst these contentions about phenomenology's inability to access epistemically purified things-in-themselves are true as far as they go, they serve to highlight the fundamental problem with the charge of idealism: that the subject/object cleavage is implicitly taken by speculative realists to be ontologically primitive in a manner denied by Merleau-Pontian phenomenologists. ${ }^{10}$ Thus, where one cannot engage with reality-in-itself

${ }^{10}$ Shaviro explicitly blames the apparent requirement for correlative mediation on the bifurcation of nature into distinct objective and subjective realms (65). However, by collapsing the subject/object distinction at the ("objective") level of the in-itself, Shaviro is no less guilty than his speculative colleagues of this very bifurcation. 
(i.e. "objective" reality), one is alpparently committed to a "subjective" prison, under which reality is subsumed into what is narrowly one's own (anthropocentric) perspective. But carnal phenomenologies, which employ a doctrine of expressive truth co-constituted by chiasmic entities, simply do not conform to this rigid subject/object schema (with its dualistic trappings) other than as a reflective abstraction. Furthermore, the main reason Merleau-Ponty cautions against “'objective' thought” (Phenomenology 71) is that, by reifying a purified realm of objects, we lose sight of our important contributions to their basic intentional physiognomy. I have suggested that it is these very contributions that radical reflection must interrogate if we are to resist the erroneous, and potentially dangerous, imposition of ontological and epistemological terms.

In fact, the acquired subject/object schema that underpins speculative realist analyses plausibly derives from the primary ambiguity experienced by body-subjects, an ambiguity necessitated by taking one's embedded implication in perspectival gestalts seriously. But this ambiguity does not make the "subject" the sole motor of truth, and this is where the charge of idealism breaks down. ${ }^{11}$ Merleau-Pontian phenomenologists can, and do, take the contributions of other entities seriously on their own terms. On my account, at least, they simply recognize that doing so requires radical reflexivity to the limitations of one's perspective and the contributions of one's sedimented history to that perspective. The important fact remains that, whilst (as Morton claims) narrowly self-reflexive critique retains a crucial role in Merleau-Pontian phenomenology, it surely cannot be the task of philosophy because its focus is too narrow. It would recognize only one stand of radical reflection (attention to sediment), at the cost of the other (attention to the contribution of the world).

If my analyses in the preceding sections hold, then Merleau-Pontian phenomenology need not be guilty of the idealism with which it is charged and which (along with the failure of dogmatic metaphysicians to recognize their own anthropocentric heritage) provides the impetus for a speculative realist turn. If I am right about this, then speculative realists also appear to be misled about the (anthropocentric) limitations of phenomenology's scope. What the analyses contained in these sections do, however, is allow us to foreground the implicit principles on which speculative realism is built and which will ultimately speak against its ability to address more-thanhuman entities in their alterity.

${ }^{11}$ There are clear parallels in objectivistic metaphysical suppositions between the false dichotomies of empiricism/intellectualism and realism/idealism. The claim that correlationism boils down to subjective mediation of objects appears to attribute a misleading sort of representationalism in Merleau-Ponty's case. 


\section{Tensions Between Anticorrelationist Realism and Alterity}

In addressing the modality of the in-itself, speculative realism's focus subtly, but importantly, shifts away from addressing one's own limitations and towards stipulative transcendental means of access that nullify one's subjective contribution. Even putting aside Merleau-Ponty's arguments for the implausibility of doing so, this shift of focus turns one's reflective attention away from the -centric overwriting of alterity, one of the very issues that was to be addressed by speculative realism. Steven Shaviro, for example, locates the motor of Kant's anthropocentrism in his "critical selfreflexivity", which should be "dislodged" on the basis that it is "too inwardlooking" (72). What instead tends to happen is that speculative realism is drawn towards reflective abstractions. Abstracting in this manner is problematic for two reasons: because the further one abstracts from grounding perceptual expressions, the risk of reflective distortion increases; and because such abstractions are more prone to concealing the contribution of the situated body-subject. Here are a few examples from the speculative realist literature to illustrate:

To avoid relying on a phenomenological opening, both Meillassoux and Brassier reduce the in-itself to inert matter. They each do so because they think that disrupting the correlationist circle requires teasing apart subject/thought from object/being. By purifying the in-itself from any necessary reliance on (human) thought or subjectivity, they hope to speculatively access metaphysically real things-in-themselves on their own terms. For Meillassoux, radically decentring thought requires resuscitating a neo-Cartesian account of primary qualities under which only "those aspects of the object that can be formulated in mathematical terms can be meaningfully conceived as properties of the object in itself" (Meillassoux 3 ; 115). For Brassier, a significant "gain in intelligibility" comes through the realization that being-in-itself is characterized by "the extinction of meaning ... the cancellation of sense, purpose and possibility" (Brassier 238).

As the ecofeminist philosopher Val Plumwood has argued, however, these sorts of schematization belie a historically-situated "truncated reversal" (121) of the Cartesian schema: a misleading anthropocentric metaphysics, minus the mind, under which "objects" are implicitly dualistically instrumentalized. Plumwood's point is that by leaving the dogmatic terms of the subject/object dualism unchallenged, a truncated reversal strategy is bound to perpetuate anthropocentric instrumentalism rather than facilitate an improvement in addressing the world on its own terms. It will do so because a truncated reversal retains the hierarchical assumption that (material or nonhuman) "objects" differ in kind from (human) "subjects" in a manner that legitimates effectively viewing the former as a resource (i.e. something that can be more-or-less exhaustively appropriated or possessed, both in the epistemic and wider senses of the 
term). At the same time, this reversal leaves human subjects to be the sole source of meaning and value. The identities of both relata of the dualism are shaped in the historical context of anthropocentric colonialism. Plumwood argues, therefore, that simply jettisoning the subject pole will not disrupt the residual Cartesian political agenda since-largely because of its sedimented metatheoretical assumptions - only a problematically impoverished conception of the more-than-human world is left behind (47).

But Meillassoux's problems do not end there because his "reversal" of the Cartesian schema is not even consistently "truncated." Shaviro suggests that Meillassoux's problematic human exceptionalism is perhaps best seen via his account of the brute emergence of subjectivity with humanity (75), a claim that would make thought radically discontinuous with the rest of the world (Harman, Meillassoux 59). Nevertheless, in the final analysis, Brassier fares little better. Brassier's exceptionalism comes with the nihilism he consistently equates with the absence of human valuers. Both dualistically cleave mind/culture/subject from body/Nature/object along anthropocentric lines that should trouble Morton as much as Plumwood.

Shaviro attempts to address these issues by rehabilitating a "paradoxical" Whiteheadian mode of reflective speculation, which, he claims, is our only means of the encountering "the world without us obliquely" (66-7). However, in doing so, Shaviro curtails the subject/object bifurcation too forcefully and collapses the distinction into a panpsychism at the level of the in-itself, under which nonhuman entities are subsumed under human categories; most notably universal sentience. Although even Merleau-Ponty argues that (non-representational) intentionality extends well into the biotic community - at least as far as dung beetles, but probably much further (Structure 123) - this only problematizes the body/mind binary. Significantly, this means that, contrary to Harman's assertion (Guerrilla 173), Merleau-Pontian Others do not have to be human. ${ }^{12}$ However, especially if one is to take seriously the possible heterogeneity of mindedness and its intrinsic relation to our concrete modes of embodiment,

\footnotetext{
${ }^{12}$ Merleau-Ponty makes this point repeatedly in The Structure of Behaviour. In its final paragraph, Merleau-Ponty argues that it is an objectivistic error to attempt to naturalize a nonhuman gestalt from a transcendental view-from-nowhere. This is why the Phenomenology is so concerned with human perception - it is a phenomenological investigation from within a certain kind of gestalt structure - not because Merleau-Ponty abandoned nonhuman intentionality. Harman seems to be unfamiliar with Merleau-Ponty's early work. Acceptance of nonhuman awareness, however, might also allow MerleauPontian phenomenology to pass Harman's litmus test in another way because it licences irreducibly more-than-human expressions of the world.
} 
Merleau-Ponty's admission certainly does not entail Shaviro's claim that "intentionality is $\ldots$ an ontological feature of objects in general" (80). ${ }^{13}$

To clarify: whilst I applaud Shaviro's rejection of Meillassoux's assumption that "thought, value, and experience are essentially, or exclusively human to begin with" (Shaviro 91), this realization has not led Shaviro to problematize the sedimented Cartesian assumptions that underpin Meillassoux's account. Shaviro ultimately admits nonhuman entities to the sphere of mindedness not by disrupting the atomistic and hierarchical terms of the subject/object dualism, but rather by anthropomorphically extending them without reserve. This has the effect that, to the extent that Shaviro may address (nonhuman) Others, their subjectivity cannot differ from his in any radical manner. Shaviro says as much when he claims that "[ $\mathrm{t}]$ he bat's inner experience is inaccessible to me, but this is so in much the same way ... that any other person's inner experience is accessible to me" (92). By making all entities "autonomous centers" (89) of life, in possession of remarkably similar atomic subjectivities, it seems Shaviro is guilty of what Plumwood calls "incorporation": the colonial (androcentric as well as narrowly anthropocentric) act of defining the underside in a manner relative to the master identity-in this case, roughly, a Cartesian subject-rather than emancipating it in its alterity. ${ }^{14}$

As I see it, the underpinning problem with each of these positions is that speculative realism's stipulation that reality cannot be gleaned from within the correlation introduces a (false) dilemma: to absolutize the object pole (Meillassoux, Brassier) or else collapse the distinction between poles at the level of the in-itself (Shaviro). Since both options are, I have suggested, plausibly derivative from the phenomenal reality co-expressed between chiasmic "world" and "subject" poles, both options erode alterity through egomorphic or anthropomorphic imposition. Why? In short, because the speculative realist requirement for unmediated access to the initself requires an objectivistic reduction to the same, yet "the same" is always gleaned from a situated and partial (if not narrowly singular) grip on the world. ${ }^{15}$ Moreover, by shifting the focus away from critical self-

13 Bennett makes a helpful distinction between subjective mentality and quasi-agency. Since Shaviro is set against brute emergence, he needs even slime moulds, thermostats, and neutrinos to possess the former. Quasi-agency, however, is not so obviously neoCartesian.

${ }^{14}$ Plumwood argues that the atomism invoked from the master perspective, for example, is fallacious outside of the logic of dualism. This means that acts of incorporation like Shaviro's are shot through with misleading sediment.

15 Although I will not explore it in depth here, the object-oriented ontology strand of speculative realism is tainted by similar errors because its concessions to alterity are either too strong or too weak. Since for object-oriented ontologists, the object itself cannot be accessed at all, the strong kind of alterity retained through object withdrawal does nothing 
reflexivity, speculative realists appear to be in a worse position than some of their phenomenological rivals to recognize and attend to such problems. If I am right about this, then, in lieu of recourse to the sort of radical reflection available to Merleau-Pontian phenomenologists, speculative realism is in a worse position than Merleau-Pontian phenomenology to engage with more-than-human entities in their alterity.

\section{So, is Merleau-Pontian Phenomenology Correlationist?}

One important consideration here surrounds any putative realism taken up. As has been noted, Merleau-Ponty does retain inescapable categories of truth and reality, but these are grounded in perceptual co-expression, rather than transcendent acquaintance with a world-in-itself (Phenomenology xvi). The mere possibility that a perceptual expression might be subsequently shattered and replaced (as happens when we realize a "rock" is really a lump of driftwood (Visible 40) does not "amount to sceptical doubt" about the world "because, in short, doubt must be lived" (James, Presence 48). Thus, the praxis of affirmation and seriousness with which the Merleau-Pontian phenomenologist addresses the real world mirrors that of avowed realists.

One other salient aspect of the Merleau-Pontian account that should be emphasized here is that since one is one's body, one is implicated in the world in one's essential carnality. Merleau-Ponty distinguishes lived-body (Leib) from corpse (Körper) but holds that the body's fundamental (subjectobject) ambiguity shows these to be inseparably intertwined as matters of degree (Phenomenology 283). Since one is ontologically "connatural" (217) with the rest of the world, therefore, "the whole of nature is the setting of our own life, or our interlocutor in a sort of dialogue" (320). The relationship articulated here is, James notes, significantly more "intimate" than that between subject and object ("Merleau-Ponty" 512). This means that, as a Merleau-Pontian body-subject, one does have direct epistemic contact with that world in a manner not true of Kant, or perhaps Husserl, because one is not bifurcated from that world in the manner that Cartesian subject/object dichotomies require. ${ }^{16}$ Speculative realist analyses, however,

to satisfy the demand to address the more-than-human world in its alterity. Neither is alterity given sufficient due with respect to the metaphorizing relations that allegedly take place between objects because the terms under which inter-objective encounters play out between nonhuman entities are exactly those found in human experience. In Harman's paradigm example, for instance, both the properties with which fire and cotton metaphorize one another, and those which withdraw - the cotton's "aroma" or the fire's "foreboding sparkle" (Harman 170) — are also freely available to us humans.

16 Perhaps the mistakenly widespread attribution of correlationism is the product of grounding a metaphysical movement in a common rejection of Kantian metaphysics. Although Kant disavows the experiential uncoupling of concepts and intuitions, he does 
are unsuited to make sense of this fact since their metaphor of "access" requires the problematic reification of ontologically distinct poles from the outset.

Furthermore, through one's embodiment, one should accept relations of significant ontological continuity with other animals and, albeit to a lesser extent, other (a)biota. Kelly Burns, for example, notes that for Merleau-Ponty, "the similarities in the ways that our bodies operate in the world lead to similarities in consciousness, which is not an isolated phenomenon, but a common experience" (110). For instance, one shares significant bodily continuities with certain other mammals, so it is plausible that at some ideal, pre-sedimented level, there are common (if gradated and heterogeneous) nondiscursive grounds of experience that testify to a shared, real world. ${ }^{17}$ Once one dispenses with the binary requirements of a rigid subject/object, or self/other schema, engagement with other entities in their alterity becomes feasible on these grounds.

We may go on: Elizabeth Grosz and Brian Massumi emphasize human-nonhuman connaturality through evolutionary continuity. Massumi does this by drawing attention to evolutionary "supernormality," which we see in Herring Gull behaviour and which infuses human creativity. MerleauPonty makes a related point by appealing to the chiasmic gestalts of matter, life and mind under which something novel (e.g. life, mind) emerges from its predecessor (Structure). ${ }^{18}$ Merleau-Ponty argues that, as embodied, "higher" gestalts themselves rely essentially on ever-present but subordinated gestalts that condition them. Subordinated levels are associated with more rudimentary ways of being-in or revealing the world. Yet, as Ted Toadvine argues, through the chiasmic contribution of subordinated levels to perceptual grip, we share partial epistemological and

arguably reify the transcendental subject in the manner problematized by speculative realism (Kant 193-4 B75/A51).

${ }^{17}$ Under this understanding, discourse "is not what is said; it is that which constrains and enables that which can be said. ... [Discursive practices] are actually historically situated social conditions" (Barad 137). To think of whole experiences as discursive/nondiscursive is misleading, because doing so requires the same anthropocentric culture/nature dualism we see manifested in objectivistic representationalism. Nevertheless, the term "nondiscursive grounds of experience" is not entirely unproblematic as I am using it here. The cross-blending of human vision, for example, is uncontroversially nondiscursive under these terms, but still particular to a relatively narrow set of organisms. The world's meaning presented through binocular vision, however, remains irreducible to these biologicallyspecific grounds. Thus, the radically-reflective body-subject must continue to question to what extent any particular nondiscursive grounds afford narrowly species-specific expressions.

${ }^{18}$ In the interest of doing justice to alterity, I suggest we resist Merleau-Ponty's rigid (and potentially anthropocentric) taxonomy, which is inessential to the broader claim about chiasmic kinship. 
ontological crossover via "lateral kinship" with such entities since we are connatural with them (274-5; Merleau-Ponty, Visible 207-8). ${ }^{19}$

In another example, Jane Bennett compellingly argues that the quasi-agential contribution of ambiguously "other" actants infuses human perception. There is, for instance, a relationship between omega fat consumption and depression, which colours perceptual norms (Bennett 41). Thus, "it is not enough to say we are 'embodied'. We are rather, an array of bodies" (113). If, as Bennett claims, we are (interrelated) assemblages like (pretty much) everything else — abiotic entities included — we have further reason to believe that there exist some such nondiscursive grounds.

The above suggests that it is plausible, via the chiasmic interrelationship of subject and (other entities in the) world that one is as a body-subject, that one will be well-positioned to express to some degree how things are for (that element of) the world itself ${ }^{20}$ without violating the alterity requirement. In short, this is because the anthropocentrism charge fails to recognize that as a body-subject, one is not exclusively, nor even entirely, "human." To deny this fact would bifurcate nature and mind in a manner that has been compellingly spoken against by speculative realists and actually forms part of Morton's argument against correlationism. Thus, we may respond to Meillassoux's two objections to what phenomenological "correlationism" entails: on the subjectivism problem, Meillassoux is mistaken because nondiscursive grounds give inescapable bases on which to assess truth claims; on the intersubjectivity problem, Meillassoux construes intersubjectivity too narrowly. By bifurcating mind and body, Meillassoux fails to recognise that one's body implicates one in the world addressed, and Others therein, in an important, if partial, manner.

We can see, therefore, contra Morton's charge, that there is a robust sense of realism taken up in Merleau-Pontian (eco)phenomenology. While

\footnotetext{
${ }^{19}$ Toadvine uses precisely this defence to respond to Meillassoux's ancestrality objection. If there is no moment of material history entirely alien to one's perceptual milieu, "there is no past which is absolutely past" (Merleau-Ponty, Structure 207). The "elemental" past outstrips the emergence of both sentience and consciousness and, therefore, any subsequent subject/object schema. The reverberation of the elemental past within one's grasp on the world, therefore, is the condition of personal time; it does not merely occur as an object within it. Thus, one has the same ambiguous sort of continuity with the elemental past as one does with the perspectives of other animals. As is also the case with other animals, ontological continuity means that one need not set the distant past up as a distinct objectin-itself with which one is (correlatively) hyper-separated.

20 This thought does not require that each thing has a perspective as in Shaviro's panpsychism. Rather, where something does have a perspective, the radically-reflective body-subject may be able to acknowledge that perspective to some (gradated) degree. Where something lacks a perspective, by being attentive to shared nondiscursive grounds of experience that underpin expressions of the world, the radically-reflective body-subject may again glean some degree of insight to other (more-than-human) perspectives of that thing.
} 
phenomenologists can be realists in the sense of seriously addressing a concrete reality accessed noninferentially, however, they are unable to commit to the definition of realism (i.e. by addressing a metaphysically distinct, "objective" thing-in-itself) required by speculative realists. Given the potentially significant crossover between ontologies and epistemologies, if the dispute about whether Merleau-Pontian phenomenology is correlationist turns entirely on a terminological point about the definition of "realism," then the correlationist charge seems to be empty, or at least not very serious.

There is, however, a remaining strand of the correlationist charge we have hitherto glossed. Given that Merleau-Ponty refuses to exhaustively assimilate "how things are for the world" into "how things are for me," this leaves him open to Meillassoux's modified correlationist charge, which holds that "[w]e can't know what the reality of the object in itself is because we can't distinguish between properties which are supposed to belong to the object and properties belonging to the subjective access to the object" (Meillassoux et al 409). ${ }^{21}$ This claim, in part, I accept. It is exactly this sort of issue that necessitates radical reflection in the first place. But given that the radically-reflective framework of Merleau-Pontian phenomenology is driven by (or is at least amenable to) a desire to understand the more-thanhuman world on its own terms, the critically-reflexive outlook this admission necessitates seems to be at odds with the detrimental outcomes supposedly caused by correlationism. Moreover, to the extent that speculative realism is speculative rather than dogmatic, especially given my arguments in the second section, neither can speculative realists plausibly escape Meillassoux's modified charge. As I have argued, by drawing our attention away from critical self-reflexivity, and therefore overstating the surety of our distinctions between "objective" and "subjective" properties, speculative realism seems to be at greater risk of instigating and perpetuating such outcomes.

\footnotetext{
${ }^{21}$ Another way of reading this claim is to focus on the ability to make a distinction between properties that are supposed to belong to the object rather than subjective access to that object. Read this way, there is a difference between speculative realism and MerleauPontian phenomenology: the former may make determinate (if fallible) claims about which properties belong to the object-in-itself, the latter cannot. I have already argued that the ability to do so, however, is either unimportant, or rests on metaphysical stipulations that are positively detrimental to appreciating the more-than-human world in its alterity.
} 


\section{Works Cited}

BARAD, Karen. "Posthumanist Performativity: Toward an Understanding of How Matter Comes to Matter." Material Feminisms. Eds. Stacy Alaimo and Susan Hekman. Bloomington: Indiana University Press, 2007. 120-154.

BARBARAS, R. The Being of the Phenomenon. Trans. Leonard Lawlor and Ted Toadvine. Bloomington: Indiana University Press, 2004.

BENNETT, Jane. Vibrant Matter: A Political Ecology of Things. London: Duke University Press, 2010.

BRASSIER, Ray. Nihil Unbound: Enlightenment and Extinction. Basingstoke: Palgrave Macmillan, 2007.

BURNS, Karen. "Warren's Ecofeminist Ethics and Merleau-Ponty's Body Subject." Ethics and the Environment 13.2 (2008): 101-118.

FISCHER, Sally. "Social Ecology and the Flesh: Merleau-Ponty, Irigaray, and Ecocommunitarian Politics." Merleau-Ponty and Environmental Philosophy: Dwelling on the Landscapes of Thought. Eds. Suzanne Cataldi and William Hamrick. New York: State University of New York Press, 2007. 206-216.

GROSZ, Elizabeth. Time Travels: Feminism, Nature, Power. Crow's Nest: Allen and Unwin, 2005.

HARMAN, Graham. Guerrilla Metaphysics: Phenomenology and the Carpentry of Things. Chicago: Open Court Press, 2005.

-. Quentin Meillassoux: Philosophy in the Making. Edinburgh: Edinburgh University Press, 2011.

HEIDEGGER, Martin. The Question Concerning Technology and Other Essays. Trans. William Lovitt. New York: Harper and Row, 1977.

HEINÄMAA, Sara. "Phenomenological Responses to Gestalt Psychology." Psychology and Philosophy: Inquiries into the Soul from Late Scholasticism to Contemporary Thought. Eds. Sara Heinämaa and Martina Reuter. Dordrecht: Springer, 2009. 263-284.

HUSSERL, Edmund. Cartesian Meditations: An Introduction to Phenomenology. Trans. Dorion Cairns. Dordrecht: Springer, 1960.

-. Logical Investigations Volume II. Trans. J.N. Finlay. New York: Routledge, 1970.

JAMES, Simon. "Merleau-Ponty, Metaphysical Realism and the Natural World.” International Journal of Philosophical Studies 15.4 (2007): 501-519. 
- The Presence of Nature: A Study in Phenomenology and Environmental Philosophy. Basingstoke: Palgrave Macmillan, 2009.

KANT, Immanuel. Critique of Pure Reason. Trans. Paul Guyer and Allen Wood. Cambridge: Cambridge University Press, 1998.

KELLY, Sean. "Seeing Things in Merleau-Ponty." The Cambridge Companion to Merleau-Ponty. Eds. Taylor Carman and Mark Hansen. Cambridge: Cambridge University Press, 2004. 74-111.

LEVINAS, Emmanuel. "Infinity and the Idea of Philosophy." Collected Philosophical Papers. Trans. Alphonso Lingis. Dordrecht: Martinus Nijhoff Publishers, 1987. 47-60.

-. Time and the Other. Trans. Richard A. Cohen. Pittsburgh: Duquesne University Press, 1987.

-. Outside the Subject. Trans. Michael Smith. Stanford: Stanford University Press. 1993.

MASSUMI, Brian. "The Supernormal Animal.” The Nonhuman Turn. Ed. Richard Grusin. Minneapolis: University of Minnesota Press, 2015. $1-18$.

MEILLASSOUX, Quentin. After Finitude: An Essay on the Necessity of Contingency. Trans. Ray Brassier. London: Continuum, 2008.

MEILlASSOUX, Quentin et al. "Speculative Realism." Collapse III. Ed. Robin Mackay. Falmouth: Urbanomic, 2007. 306-449.

MERLEAU-PONTY, Maurice. Phenomenology of Perception. Trans. Colin Smith. London: Routledge, 1962.

- The Structure of Behaviour. Trans. Alden L. Fisher. London: Methuen, 1965.

-. The Visible and the Invisible. Trans. Alphonso Lingis. Evanston: Northwestern University Press, 1968.

MORTON, Timothy. "Ecologocentrism: Unworking Animals." Substance 37.3 (2008): 73-96.

—. "Here Comes Everything: The Promise of Object-Oriented Ontology." Qui Parle 19.2 (2011): 163-190.

PLUMWOOD, Val. Feminism and the Mastery of Nature. London: Routledge, 1993.

REYNOLDS, Jack. Merleau-Ponty and Derrida: Intertwining Embodiment and Alterity. Athens: Ohio University Press, 2004.

RICHMOND, Scott. C. "Speculative Realism is Speculative Aesthetics (Three New Books on Speculative Realism)." Configurations 23.3 (2015): 399-403. 
ROLSTON, Holmes. "Nature for Real: Is Nature a Social Construct?" The Philosophy of the Environment. Ed. Timothy Chappell. Edinburgh: Edinburgh University Press, 1997. 38-64.

SHAVIRO, Steven. The Universe of Things. Minneapolis: University of Minnesota Press, 2014.

SPARROW, Tom. The End of Phenomenology: Metaphysics and the New Realism. Edinburgh: Edinburgh University Press, 2014.

TOADVINE, Ted. "The Elemental Past." Research in Phenomenology 44 (2014): 262-279. 